\title{
Initial growth of Brachiaria subquadripara (Trin.) Hitchc. plants under different nutritional conditions
}

\author{
Vanessa D. Domingos ${ }^{1}$, Dagoberto Martins ${ }^{2}$, Neumarcio V. Costa ${ }^{3}$, \\ Andreia C. P. R. da Costa ${ }^{4} \&$ Sidnei R. de Marchi ${ }^{5}$ \\ ${ }^{1}$ Instituto Federal de Educação, Ciência e Tecnologia do Tocantins. Palmas, TO. E-mail: vanessadd@ifto.edu.br \\ ${ }^{2}$ Faculdade de Ciências Agrárias e Veterinárias de Jaboticabal/Universidade Estadual Paulista Júlio de Mesquita Filho. Jaboticabal, SP. E-mail: \\ dmartins@fca.unesp.br \\ ${ }^{3}$ Centro de Ciências Agrárias/Universidade Estadual do Oeste do Paraná. Marechal Cândido Rondon, PR. E-mail: neumarcio.costa@unioeste.br \\ (Corresponding author) \\ ${ }^{4}$ Universidade Estadual de Maringá/Campus Regional de Umuarama. Umuarama, PR. E-mail: andreiacpr@hotmail.com \\ ${ }^{5}$ Universidade Federal de Mato Grosso/Instituto das Ciências Exatas e da Terra. Barra do Garcas, MT. E-mail: sidneimarchi.ufmt@gmail.com
}

\section{Key words:}

Urochloa subquadripara

Urochloa arrecta

aquatic plant

weed

eutrophication

water reservoir

\begin{abstract}
A B S T R A C T
The objective of this study was to evaluate the initial growth of emergent plants of Brachiaria subquadripara under different conditions of availability levels of the nutrients nitrogen $(\mathrm{N})$, phosphorus $(\mathrm{P})$, and potassium $(\mathrm{K})$ provided to the plants via nutrient solution in a greenhouse. The treatments consisted of five concentrations of $\mathrm{N}(0,42.0,84.0,126.0$, and $\left.168.0 \mathrm{mg} \mathrm{L}^{-1}\right)$, five concentrations of $\mathrm{P}\left(0,6.2,12.4,18.6\right.$, and $\left.24.8 \mathrm{mg} \mathrm{L}^{-1}\right)$ and five concentrations of $\mathrm{K}\left(0,46.8,93.6,140.4\right.$, and $\left.187.2 \mathrm{mg} \mathrm{L}^{-1}\right)$ which were adapted from a base solution. The results showed that the initial growth of plants was slow up to 21 days after transplantation (DAT) and it increased in accordance with increments in N, P, and K concentrations in the nutrient solution up to the end of the study (35 DAT). The Relative Growth Rate and the Net Assimilation Rate of the B. subquadripara plants were larger when the N, P, and K concentrations were of $84.0,18.6$, and $46.8 \mathrm{mg} \mathrm{L}^{-1}$, respectively. These results suggest that this species can develop in environments considered hypereutrophic.
\end{abstract}

\section{Palavras-chave:}

Urochloa subquadripara

Urochloa arrecta

planta aquática

planta daninha

eutrofização

reservatórios hidrelétricos

\section{Crescimento inicial de Brachiaria subquadripara (Trin.) Hitchc. em diferentes condições nutricionais}

\section{R E S U M O}

Propôs-se, neste trabalho, avaliar o crescimento inicial emergindo Brachiaria subquadripara em diferentes condições de disponibilidade dos nutrientes nitrogênio $(\mathrm{N})$, fósforo $(\mathrm{P})$ e potássio $(\mathrm{K})$ via solução nutritiva em casa-de-vegetação. Os tratamentos se constituíram de cinco doses de $\mathrm{N}\left(0,42,0,84,0126,0\right.$ e $\left.168,0 \mathrm{mg} \mathrm{L}^{-1}\right)$, cinco doses de $\mathrm{P}(0,6,2,12,4,18,6$ e 24,8 $\left.\mathrm{mg} \mathrm{L}^{-1}\right)$ e cinco doses de $\mathrm{K}\left(0,46,8,93,6,140,4\right.$ e $\left.187,2 \mathrm{mg} \mathrm{L}^{-1}\right)$ adaptadas a solução base. Os resultados demonstraram que o crescimento inicial das plantas foi lento até os 21 dias após o transplante (DAT) e crescente de acordo com os aumentos das concentrações de N, P e K em solução nutritiva até o final do experimento (35 DAT). A Taxa de Crescimento Relativo e a Taxa de Assimilação Líquida da B. subquadripara foram maiores nas concentrações de $84,0,18,6$ e 46,8 $\mathrm{mg} \mathrm{L}^{-1}$ de N, P e K, respectivamente. Esses resultados sugerem que esta espécie pode se desenvolver em ambientes considerados hipereutróficos. 


\section{INTRODUCTION}

Trophic conditions of rivers, lakes, and reservoirs mainly in the South and Southeast regions of Brazil have been altered principally by the influx of nutrients from agricultural activities, urban sewage, and industrial residues (Bini et al., 1999; Cavenaghi et al., 2003). Consequently, the intense colonization of polluted water bodies by aquatic plants has increasingly become a real possibility due to the favorable conditions for plant growth brought about by the increased availability of nutrients (O'Hare et al., 2010).

Due to the unpredictable growth shown by aquatic plants in reservoirs, several studies have been carried out to understand their biology and distribution as along with alternative control methods to find more appropriate management of these plants (Bini et al., 1999; Martins et al., 2009). One of these studies identified 39 species belonging to 21 families found in five hydrographic basins of the state of São Paulo, Brazil. Brachiaria subquadripara (Trin.) Hitchc. was among them and was one of the more frequent in the evaluated reservoirs (Martins et al., 2008).

B. subquadripara (= Urochloa subquadripara) is a member of the Poaceae family and it is native to Africa. Its characteristics are of a perennial plant which easily colonizes wet environments, mainly the margins of water bodies and rice producing areas. It shows high efficiency in the use of environmental resources and it grows quickly. It is resistant to temporary flooding and all those characteristics make it an aggressive invader of several environments (Kissmann \& Groth, 1997; González \& Morton, 2005; Mormul et al., 2010).

The success with which $B$. subquadripara plants colonize several aquatic environments may be ascribed to the allocation of biomass and nutrients for specific organs of the plant (stem, leaves, roots), the fragmentation of these vegetative organs is the main propagation means of this species as well as the formation of plant coverings which depends on nutritional resources stored in the plant (Barrat-Segretain et al., 1998). These characteristics are thought to be responsible for $B$. subquadripara being capable of suppressing other competitors (Thomaz \& Bini, 1998; Domingos et al., 2011).

Notwithstanding all this accumulated amount of knowledge about this species, in Brazil few are the studies concerning B. subquadripara biology and growth pattern as influenced by non biotic factors such as $\mathrm{N}, \mathrm{P}$, and $\mathrm{K}$ concentrations in the water. It is though believed that the growth analysis by means of physiological indices may be used for the evaluation of the productivity ecological adaptation in addition to the interference potential in eutrophic environments (Thomaz et al., 2007; Henry-Silva et al., 2008) and, consequently, provide subsidies for the development of integrated and sustainable management methods for the control of this species.

So, the objective of this research work was to evaluate the initial growth of greenhouse-grown B. subquadripara plants under different availability levels of N, P, and $\mathrm{K}$ in a nutrients solution.

\section{Material AND Methods}

B .subquadripara plants were collected at their occurrence environment at the Barra Bonita Hydroelectric Power Plant at Barra Bonita city (latitude of $22^{\circ} 46^{\prime} 4^{\prime \prime}$ S, longitude of $48^{\circ}$ 9' 41" WGr. and at a mean altitude of $457 \mathrm{~m}$ above sea level), state of São Paulo, Brazil. The period of the experiment was 2006-2007. The plants were multiplied in a greenhouse in fifty plastic pots $(13.8 \times 28.3 \times 11.8 \mathrm{~cm})$ filled with a soil classified as a dark Red Latosol with a medium texture showing the following characteristics: $\mathrm{pH}\left(\mathrm{CaCl}_{2}\right)=4.1$; organic matter $(\mathrm{g}$ $\left.\mathrm{dm}^{-3}\right)=18.0 ; \mathrm{P}\left(\mathrm{mg} \mathrm{dm}^{-3}\right)=8.0 ; \mathrm{H}+\mathrm{Al}, \mathrm{K}, \mathrm{Ca}, \mathrm{Mg}, \mathrm{SB}$, and CTC (cation exchange capacity) $\left(\mathrm{mmol}_{c} \mathrm{dm}^{-3}\right)=67.0,0.1,1.0$, 1.0, 2.0, and 68.0, respectively; $\mathrm{V} \%=3.0$.

In each pot was transferred 1 plant with three internodes in the stem, two to three open leaves starting from the apex and no roots. The plants remained in the pots above a water depth of $5 \mathrm{~cm}$. For better standardization of the seedlings before transplanting in pots with nutrient solution, the plants were kept in the pots for 48 days and received an application of $30 \mathrm{~mL} \mathrm{pot}^{-1}$ at 15 day intervals of a urea solution with a concentration of $4.5 \%$ of N. During this period there were two pruning to avoid tillering.

A preliminary study was undertaken to find out the most adequate nutrients solution (base solution) for the growth of $B$. subquadripara plants. To find the base solution, the nutrients solution Sarruge (1975) was diluted several times. Results showed that diluting Sarruge's solution to $20 \%$ of its original concentration yielded the best solution for the nutritional demand of B. subquadripara plants. This base solution had concentrations of $168.0,24.8,187.2,160.0,38.4$, and 51.2 $\mathrm{mg} \mathrm{L}^{-1}$ of, respectively, $\mathrm{N}, \mathrm{P}, \mathrm{K}, \mathrm{Ca}, \mathrm{Mg}$, and $\mathrm{S}$. It also had concentrations of 4, 0.4, 0.4, 0.0016, and $0.0008 \mathrm{mg} \mathrm{L}^{-1}$ of FeEDTA, B, Mn, $\mathrm{Zn}, \mathrm{Cu}$, and Mo, respectively. The solution $\mathrm{pH}$ was of $6.0 \pm 0.5$. The treatments consisted of five concentrations of $\mathrm{N}\left(0,42.0,84.0,126.0\right.$, and $\left.168.0 \mathrm{mg} \mathrm{L}^{-1}\right)$, five concentrations of $\mathrm{P}\left(0,6.2,12.4,18.6\right.$, and $\left.24.8 \mathrm{mg} \mathrm{L}^{-1}\right)$ and five concentrations of $\mathrm{K}\left(0,46.8,93.6,140.4\right.$, and $\left.187.2 \mathrm{mg} \mathrm{L}^{-1}\right)$ which were adapted from a base solution. These concentrations correspond to hypereutrophic environment (Toledo Júnior, 1990).

The plants were transplanted to plastic recepients containing $1 \mathrm{~L}$ of the basic solution with the respective treatments. A plant was understood as including part of a tiller with three internodes in the stem, two to three open leaves starting from the apex and no roots. These plants were fixed in phenolic foam which was embedded in expanded polystyrene which was perforated to fix the air distributing tube stopped with a cotton wad to avoid the entrance of light and the consequent algae proliferation. The nutrient solution was renewed at each 7 days and the $\mathrm{pH}$ of the solution was daily adjusted to $6.0 \pm$ 0.5 during the whole experimental period.

Evaluations began 7 days after the transplantation (DAT) of the plants to the nutrient solution and that date was considered as 0 DAT. The growth analysis of $B$. subquadripara plants was based on plants collected at 7, 14, 21, 28, and 35 DAT. The growth analysis was based on the evaluation of the following biometric parameters: leaf area, leaves, roots, and the whole plant (leaves, stem, and roots) dry matter. To determine the physiological indices, the following characteristics were estimated: relative growth rate (RGR), leaf area ratio (LAR), and net assimilation rate (NAR) in relation to the DAT, which were established by the ANACRES program (Portes \& Castro Júnior, 1991). 
The study was carried out according to a completely random design with six replications. The treatments with levels of $\mathrm{N}$, $\mathrm{P}$, and $\mathrm{K}$ were individually analysed in a factorial scheme $5 \mathrm{x}$ 5 (5 nutrient concentration levels in the nutrient solution and 5 collecting times). The results were submitted to the analysis of variance by the $\mathrm{F}$ test $(\mathrm{p} \leq 0.05)$ whereas the means were submitted to a regression analysis. The statistical program 'SigmaStat 2.0' was used. The regression model was chosen on the basis of coefficient of determination, regression significance ( $\mathrm{p} \leq 0.05)$, and the normality test.

The results of the physiological indices estimated by the ANACRES program, since they are calculated values, do not obey the basic assumptions for the analysis of variance. So, the indices were presented graphically for the evaluation of the growth curves behavior (Portes \& Castro Júnior, 1991).

\section{Results AND Discussion}

The analysis of variance results show that there was a significant interaction between the nutrients $\mathrm{N}, \mathrm{P}$, and $\mathrm{K}$ concentrations and the collect times for leaf dry matter, plant dry matter, and leaf area (Table 1).

At 35 DAT B. subquadripara showed increasing accumulation of dry matter in leaves and plant (total) to $50 \%$ of the concentration used of N, P and K. From that level upwards for each nutrient there was a severe reduction mainly in the concentrations of $168.0,24.8$, and $187.2 \mathrm{mg} \mathrm{L}^{-1}$ of $\mathrm{N}, \mathrm{P}$, and $\mathrm{K}$, respectively (Figure 1). A similar behavior was observed when plant leaf area was examined (Figure 2).

Thus, at the end of the study, the highest amounts of accumulated dry matter as determined by $\mathrm{N}$ were observed when the concentrations of this element were of 42.0, 84.0, and $126.0 \mathrm{~g} \mathrm{~L}^{-1}$ with means of $6.1 \pm 0.4,11.1 \pm 1.4$, and $10.1 \pm$ 0.7 of dry matter in g plant $^{-1}$, respectively (Figure $3 \mathrm{~A}$ ). When phosphorus is examined, it is seen that the highest amounts of accumulated dry matter were of $7.5 \pm 0.3,8.5 \pm 0.2$, and $7.9 \pm$ 0.5 g plant $^{-1}$ when $\mathrm{P}$ concentrations were, respectively, of 6.2 , 12.4 , and $18.6 \mathrm{mg} \mathrm{L}^{-1}$ (Figure 3B). K, at the concentrations of $46.8,93.6$, and $140.4 \mathrm{mg} \mathrm{L}^{-1}$, resulted in the highest amounts of accumulated dry matter, that is, $7.7 \pm 0.8,9.8 \pm 0.7$, and 8.7 \pm 0.9 g plant $^{-1}$, respectively (Figure $3 \mathrm{C}$ ). It was verified that the concentrations of $168.0,24.8$, and $187.2 \mathrm{mg} \mathrm{L}^{-1}$ of N, P, and $\mathrm{K}$ resulted in the lowest amounts of plant accumulated dry matter. These results were similar to those produced by the control treatment (without the addition of nutrients).
The amounts of accumulated dry matter by the leaves and the plants leaf area were similar to those of plants accumulated dry matter (Figure 4).
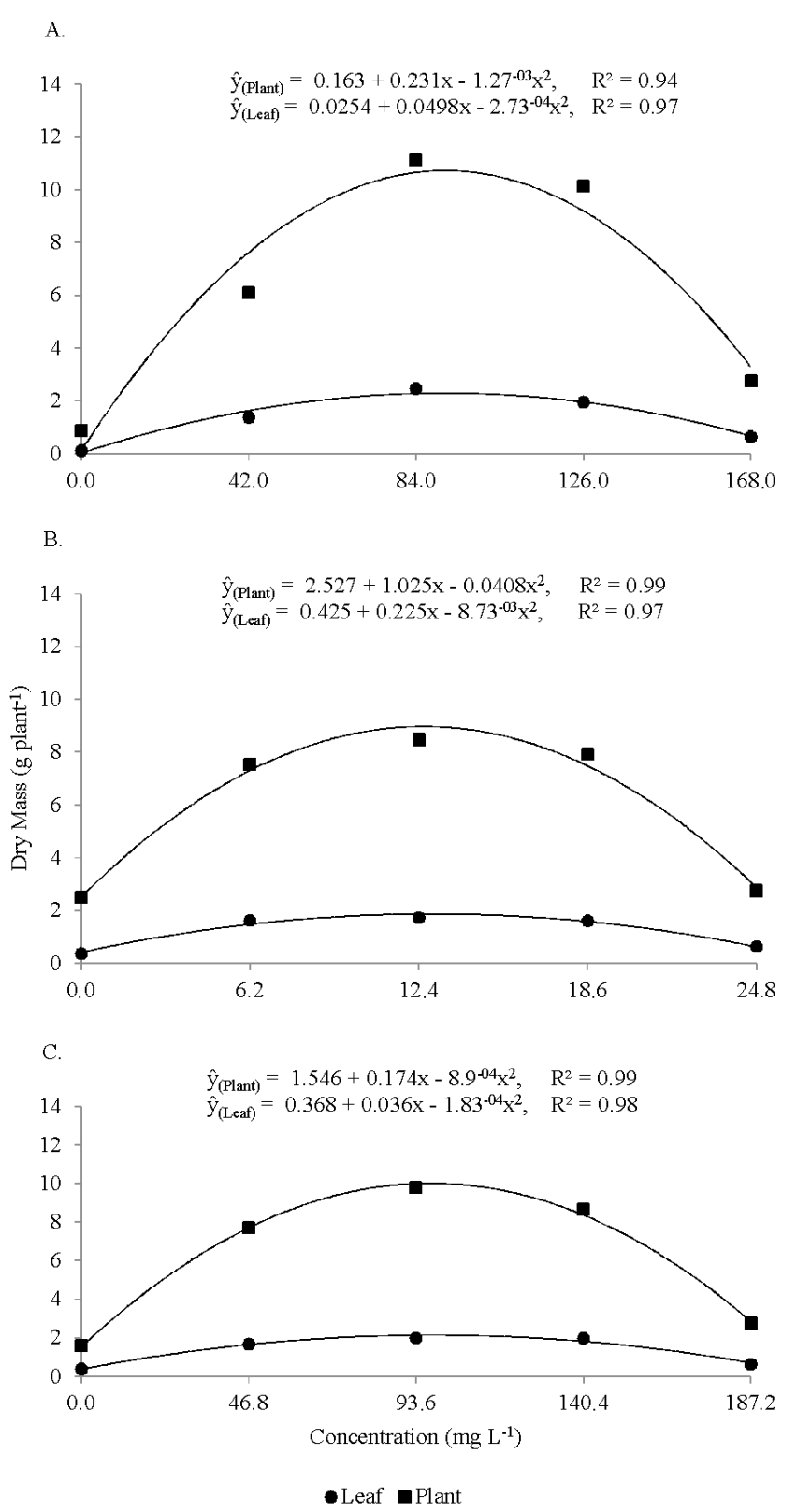

Figure 1. Leaves and plants dry mass, 35 days after seedling transplant, of $B$. subquadripara plants under different nitrogen $(A)$, phosphorus $(B)$, and potassium $(C)$ concentrations

Table 1. F values of the analysis of variance for nitrogen $(\mathrm{N})$, phosphorus (P), and potassium (K); $N=150$ (for each nutrient)

\begin{tabular}{|c|c|c|c|}
\hline Sources of variation & Leaf dry mass & Plant dry mass & Leaf area \\
\hline \multicolumn{4}{|l|}{ 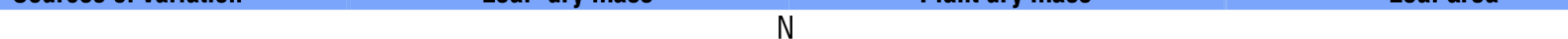 } \\
\hline Concentrations (C) & $24.167(P<0.001)$ & $34.040(P<0.001)$ & $34.886(P<0.001)$ \\
\hline Time $(\mathrm{T})$ & $104.420(P<0.001)$ & $130.330(P<0.001)$ & $109.704(\mathrm{P}<0.001)$ \\
\hline $\mathrm{C} \times \mathrm{T}$ & $10.172(P<0.001)$ & $14.205(\mathrm{P}<0.001)$ & $13.300(P<0.001)$ \\
\hline \multicolumn{4}{|c|}{$17.200(1-0.001)$} \\
\hline Concentrations (C) & $18.133(P<0.001)$ & $24.318(P<0.001)$ & $34.892(P<0.001)$ \\
\hline Time $(\mathrm{T})$ & $89.968(\mathrm{P}<0.001)$ & $173.002(\mathrm{P}<0.001)$ & $163.807(P<0.001)$ \\
\hline $\mathrm{C} \times \mathrm{T}$ & $5.831(\mathrm{P}<0.001)$ & $9.961(P<0.001)$ & $10.058(P<0.001)$ \\
\hline \multicolumn{4}{|c|}{$\mathrm{K}$} \\
\hline Concentrations (C) & $16.076(P<0.001)$ & $16.136(\mathrm{P}<0.001)$ & $23.278(P<0.001)$ \\
\hline Time (T) & $105.660(P<0.001)$ & $123.532(\mathrm{P}<0.001)$ & $176.641(\mathrm{P}<0.001)$ \\
\hline $\mathrm{C} \times \mathrm{T}$ & $7.049(\mathrm{P}<0.001)$ & $10.575(P<0.001)$ & $13.520(P<0.001)$ \\
\hline
\end{tabular}



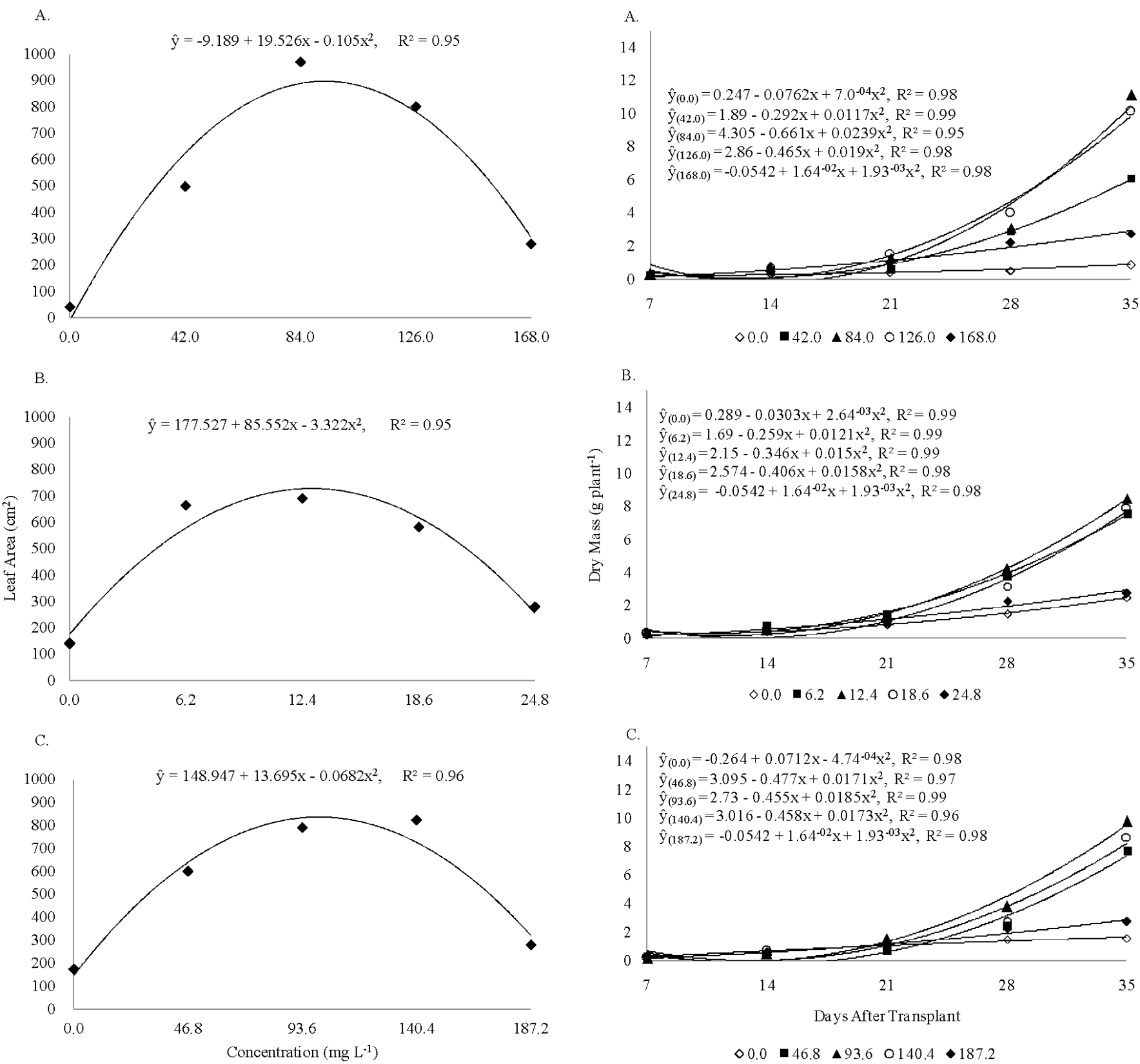

Figure 2. Leaf area, 35 days after seedling transplant, of $B$. subquadripara plants under different nitrogen (A), phosphorus (B), and potassium (C) concentrations

The relative growth rate (RGR) is a measure of the increment in dry weight of a plant or of any organ of that plant during a period of time. In Figure $5 \mathrm{~A}$ it is seen that the B. subquadripara plants showed increasing RGR values as $\mathrm{N}$ concentrations increased, mainly at the concentrations of 42.0 , 84.0 , and $126.0 \mathrm{mg} \mathrm{L}^{-1}$.

The concentration of $0 \mathrm{mg} \mathrm{L}^{-1}$ of $\mathrm{N}$ in the nutrient solution resulted in RGR relatively constant during the evaluation period with a mean of $0.05 \mathrm{~g} \mathrm{~g}^{-1} \mathrm{~d}^{-1}$ respectively (35 DAT). On the other hand, at the concentration of $168.0 \mathrm{mg} \mathrm{L}^{-1}$ of $\mathrm{N}$ in the nutrient solution the RGR values underwent a decrease as the evaluation period increased.

The concentration of $84.0 \mathrm{mg} \mathrm{L}^{-1}$ of $\mathrm{N}$ was considered a limit concentration for the RGR; increments above that value may cause reductions in RGR readings during plant growth.

The results for the concentrations of $\mathrm{P}$ (Figure $5 \mathrm{~B}$ ) show that the RGR values increased at the concentrations of $6.2,12.4$, and

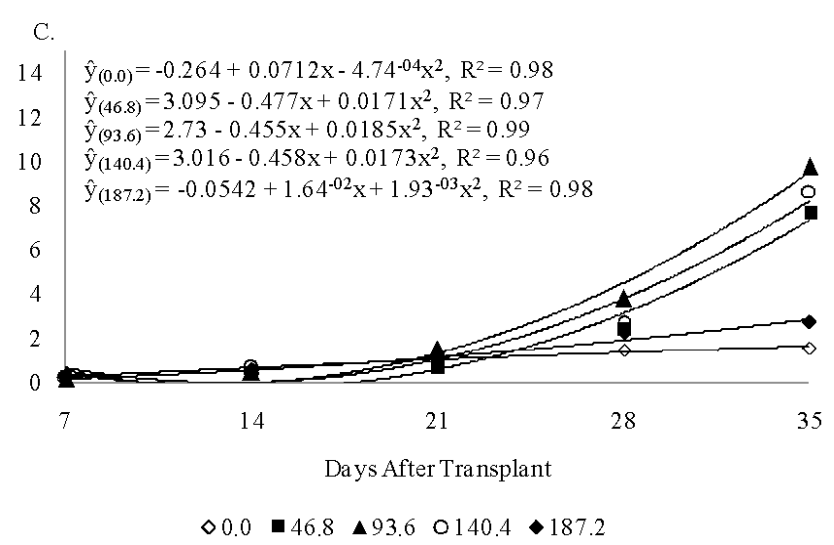

Figure 3. Dry mass of $B$. subquadripara plants under different nitrogen (A), phosphorus (B), and potassium (C) concentrations during a period of 35 days after seedling transplant

$18.6 \mathrm{mg} \mathrm{L}^{-1}$ during the evaluation period in which the means were of $0.14,0.15$, and $0.17 \mathrm{~g} \mathrm{~g}^{-1} \mathrm{~d}^{-1}$, respectively, at $35 \mathrm{DAT}$. On the other hand, at the $\mathrm{P}$ concentrations of 0 and $24.8 \mathrm{mg} \mathrm{L}^{-1}$ reductions in RGR, were observed as the plants developed.

For the concentrations of $\mathrm{K}$ (Figure 5C) it was observed that the highest RGR value resulted when the $K$ concentration was of $46.8 \mathrm{mg} \mathrm{L}^{-1}$ with an average of $0.21 \mathrm{~g} \mathrm{~g}^{-1} \mathrm{~d}^{-1}$ at 35 DAT.

It was observed a general tendency of decreasing leaf area ratio (LAR) as the plants grew. The $\mathrm{N}$ concentration of 168.0 $\mathrm{mg} \mathrm{L}^{-1}$ caused the highest LAR with a mean of $1.0 \mathrm{dm}^{2} \mathrm{~g}^{-1}$ at 35 DAT (Figure 6A).

When the $\mathrm{P}$ effects are analysed, it is seen that the maximum LAR was reached at 21 DAT and, after that period, LAR decreased for the concentrations of $6.2,12.4$, and $18.6 \mathrm{mg} \mathrm{L}^{-1}$ (Figure 6B). 

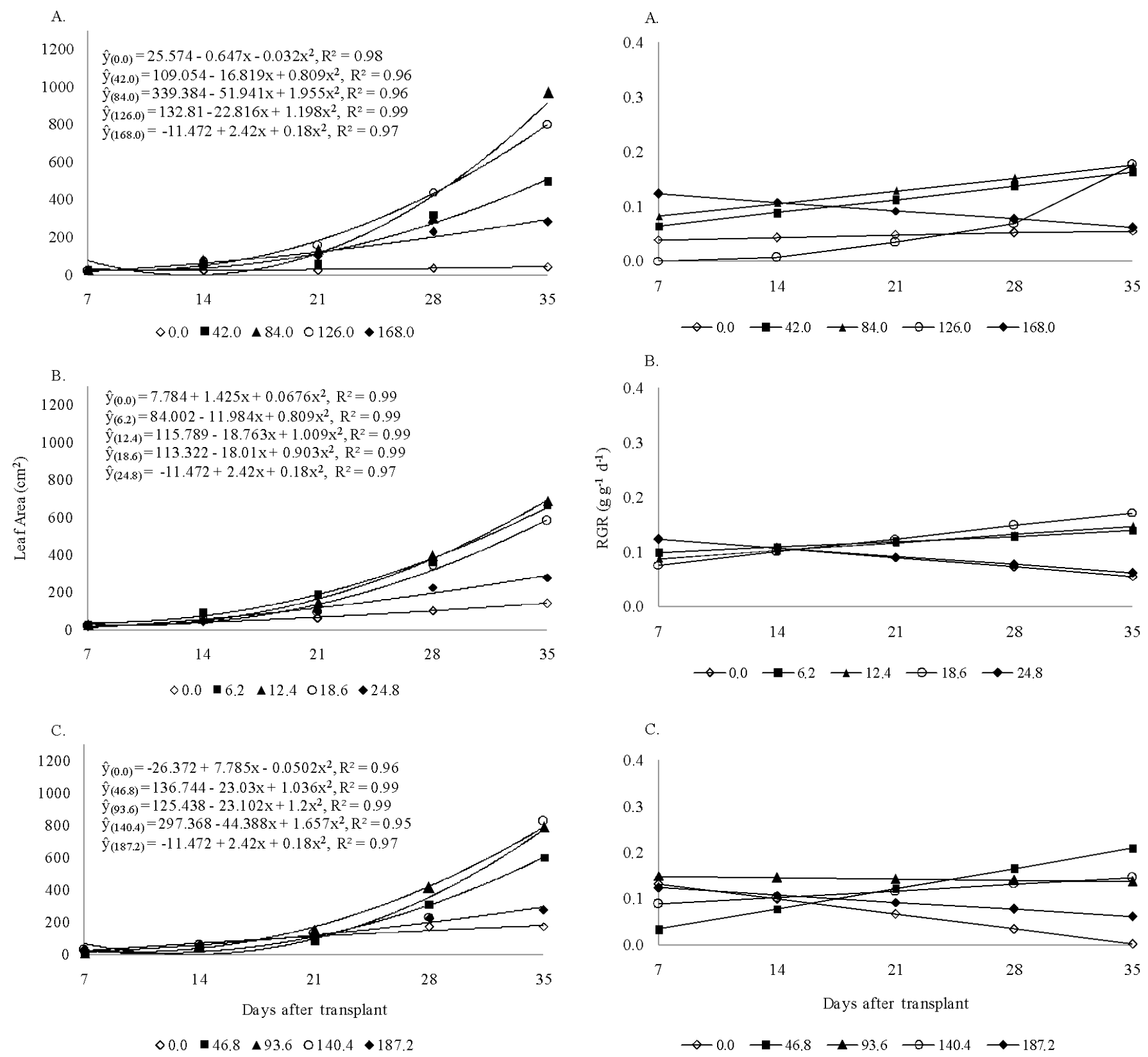

Figure 4. Leaf area of $B$. subquadripara plants under different nitrogen $(A)$, phosphorus $(B)$, and potassium $(C)$ concentrations during a period of 35 days after seedling transplant

LAR values for the $\mathrm{K}$ concentrations of 46.8 and 93.6 $\mathrm{mg} \mathrm{L}^{-1}$ of $\mathrm{K}$ in the nutrient solution were highest at 21 DAT. But, at the end of the experiment the observed values were close to those observed at the beginning of the evaluations (Figure 6C).

The efficiency in the use of solar radiation or net assimilation rate (NAR) by B. subquadripara plants at the first week is observed to increase with $\mathrm{N}$ concentration, except the concentration of $126.0 \mathrm{mg} \mathrm{L}^{-1}$ (Figure 7A). But, the mean NAR value at 35 DAT were of $0.18,0.23$, and $0.20 \mathrm{~g}$ $\mathrm{dm}^{3}$ correspondents to the $\mathrm{N}$ concentrations of $42.0,84.0$, and $126.0 \mathrm{mg} \mathrm{L}^{-1}$, respectively. When the $\mathrm{N}$ concentration in the nutrient solution was of $168.0 \mathrm{mg} \mathrm{L}^{-1}$, decrease in NAR values were observed during the experimental period.

The $\mathrm{P}$ concentration in the nutrient solution of $18.6 \mathrm{mg} \mathrm{L}^{-1}$ resulted in the highest NAR value at $35 \mathrm{DAT}$ (Figure 7B). But,

Figure 5. Relative growth rate (RGR) of $B$. subquadripara plants under different nitrogen (A), phosphorus (B), and potassium (C) concentrations during a period of 35 days after seedlings transplant

at $7 \mathrm{DAT}$ the $\mathrm{P}$ concentration of $24.8 \mathrm{mg} \mathrm{L}^{-1}$ led to the highest NAR values. But as time passed by, significant reductions in NAR values were observed. When $P$ was absent, NAR values were practically constant during the evaluated period.

As to $\mathrm{K}$ (Figure 7C), it was observed that in the absence of this nutrient the assimilating system was significantly affected since NAR showed drastic reductions during the evaluation period. On the other hand, the $\mathrm{K}$ concentration of $46.8 \mathrm{mg} \mathrm{L}^{-1}$ was enough to result in the highest values of that parameter at $35 \mathrm{DAY}$, although the values observed in the first week were lower than those of the other evaluated concentrations.

In the Barra Bonita hydroelectric power plant reservoir, Domingos et al. (2011) reported to have found nitrogen (N total), phosphorus $\left(\mathrm{PO}_{4}^{3-}\right)$, and potassium $(\mathrm{K})$ concentrations in the water of 55,$2 ; 77,5$, and $17.2 \mathrm{mg} \mathrm{L}^{-1}$, respectively. 

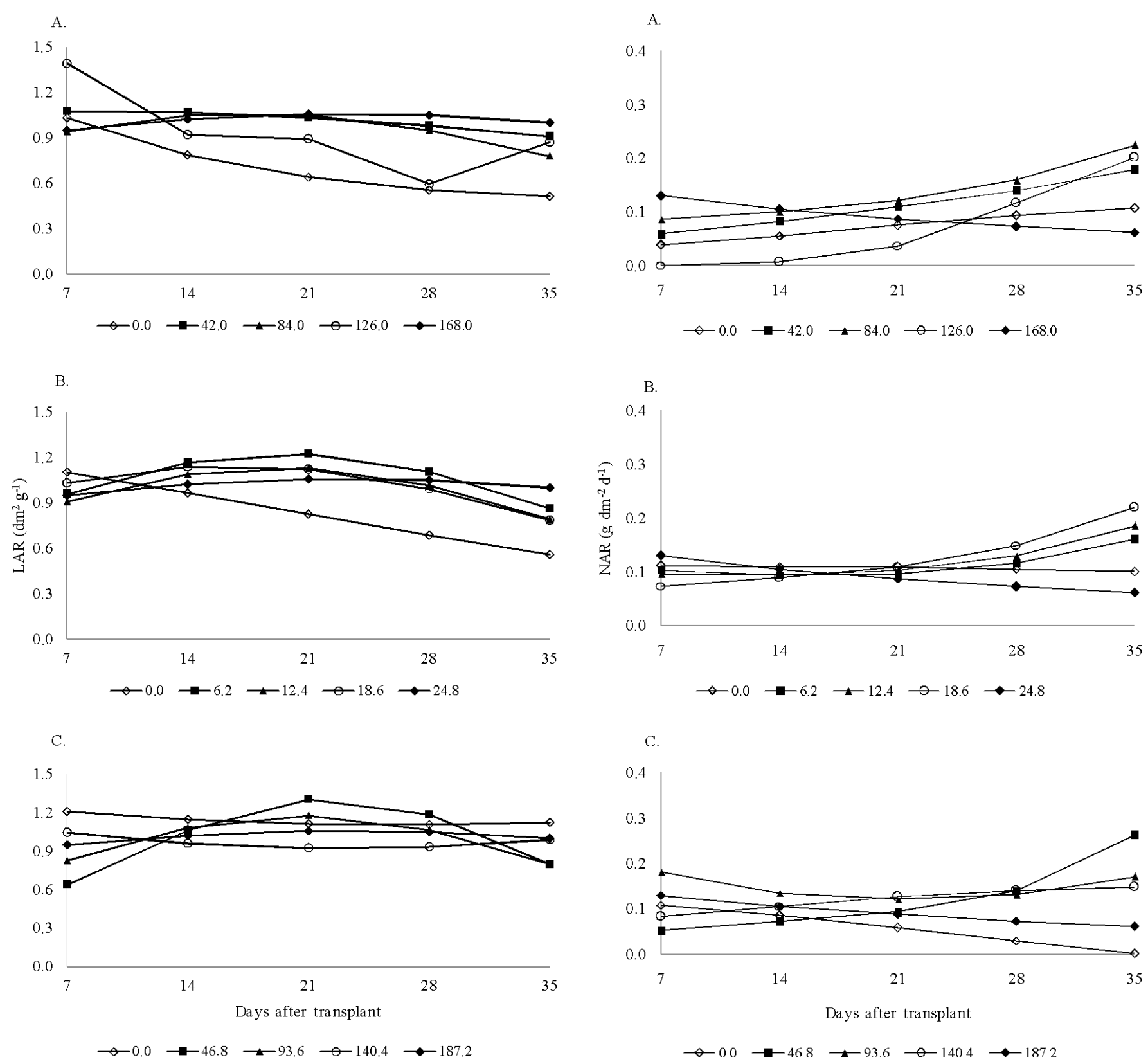

Figure 6. Leaf area ratio (LAR) of B. subquadripara plants under different nitrogen (A), phosphorus $(B)$, and potassium (C) concentrations during a period of 35 days after seedlings transplant

Cavenaghi et al. (2003) observed correlation of these nutrients with the occurrence of large infestations of B. subquadripara, in five reservoirs of the Tietê watershed (São Paulo, Brasil) used to produce electrical energy.

In the present study, the initial growth of B. subquadripara plants increased in agreement with the increasing concentrations of $\mathrm{N}, \mathrm{P}$, and $\mathrm{K}$ in the nutrients solution. But, in the highest concentrations of these nutrients, reductions in the leaves dry mass, of the whole plant as well as in leaf area were observed, showing that, when the concentrations of these elements are in excess $\left(168.0,24.8\right.$, and $187.2 \mathrm{mg} \mathrm{L}^{-1}$ of N, P, and $\mathrm{K}$, respectively), they may act as a limiting factor for the establishment of plants of that species in aquatic environments.

It is noteworthy that this condition may represent the maximum tolerated hypertrophication by plants of $B$.

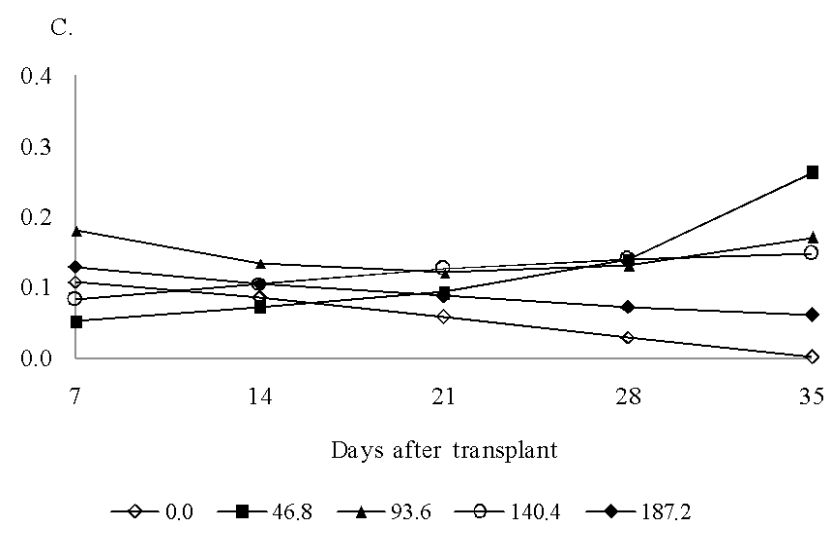

Figure 7. Net assimilation rate (NAR) of $B$. subquadripara plants under different nitrogen (A), phosphorus (B), and potassium $(C)$ concentrations during a period of 35 days after seedling transplant

subquadripara and that probably this condition was negative interaction of $\mathrm{N}, \mathrm{P}$ and $\mathrm{K}$ with the absorption of micronutrients by the plant. But is still not clear the mechanism that allows the plant $B$. subquadripara tolerate high levels of nutrients dissolved in water. These results confirm those reported by Lacoul \& Freedman (2006).

Xie et al. (2004) verified that Eichhomia crassipes plants growth and propagation are stimulated when $\mathrm{N}$ and $\mathrm{P}$ availability in the medium where the plants are is regularly augmented. It is, nonetheless, necessary to emphasize that the concentrations used by those authors ( 0 to $1 \mathrm{mg} \mathrm{L}^{-1}$ of $\mathrm{P}$ and 0 to $10 \mathrm{mg} \mathrm{L}^{-1}$ of $\mathrm{N}$ ) may be considered low in comparison with those used in this work.

Nothwithstanding the difficulties in establishing the concentration limits which characterize mesotrophic, eutrophic and hypereutrophic conditions (Tundisi et al., 2008) 
it can be concluded that $B$. subquadripara plants exhibited good development under hypereutrophic conditions (42.0 to $126.0 \mathrm{mg} \mathrm{L}^{-1}$ of N, 6.2 to $18.6 \mathrm{mg} \mathrm{L}^{-1}$ of P and 46.8 to $140.4 \mathrm{mg}$ $\mathrm{L}^{-1}$ of $\mathrm{K}$ ) although they did not tolerate conditions considered extremely hypereutrophic in the experiment $\left(168.0 \mathrm{mg} \mathrm{L}^{-1}\right.$ of $\mathrm{N}, 24.8 \mathrm{mg} \mathrm{L}^{-1}$ of $\mathrm{P}$, and $187.2 \mathrm{mg} \mathrm{L}^{-1}$ of $\mathrm{K}$ ).

\section{Conclusions}

1. The plant growth of B. subquadripara responded to the quadratic model with increased levels of $\mathrm{N}, \mathrm{P}$ and $\mathrm{K}$ in the nutrient solution, as well as the evaluated physiological indices.

2. Under conditions of excess or deficiency of these nutrients in the nutrient solution, relative growth rate and net assimilation rate tend to undergo reductions during the initial growth of the plants.

\section{Literature Cited}

Barrat-Segretain, M. H.; Bornette, G.; Vilas-Bôas, A. H. Comparative abilities of vegetative regeneration among aquatic plants growing in disturbed habitats. Aquatic Botany, v.60, p.201-211, 1998. http:// dx.doi.org/10.1016/S0304-3770(97)00091-0

Bini, L. M.; Thomaz, S. M.; Murphy, K. J.; Camargo, A. F. M. Aquatic macrophyte distribution in relation to water and sediment conditions in the Itaipu Reservoir Brazil. Hydrobiologia, v.415, p.147-154, 1999. http://dx.doi.org/10.1023/A:1003856629837

Cavenaghi, A. L.; Velini, E. D.; Galo, M. L. B. T.; Carvalho, F. T.; Negrisoli, E.; Trindade, M. L. B.; Simionato, J. L. A. Caracterização da qualidade de água e sedimento relacionados com a ocorrência de plantas aquáticas em cinco reservatórios da bacia do rio Tietê. Planta Daninha, v.21, p.43-52, 2003. http://dx.doi.org/10.1590/ S0100-83582003000400007

Domingos, V. D.; Martins, D.; Costa, N. V.; Marchi, S. R.; Rodrigues-Costa, A. C. Alocação de biomassa de Brachiaria subquadripara sob diferentes concentrações de N, P e K. Planta Daninha, v.29, p.25-36, 2011. http://dx.doi.org/10.1590/S010083582011000100004

González, A. M. T.; Morton, C. M., Molecular and morphological phylogenetic analysis of Brachiaria and Urochloa (Poaceae). Molecular Phylogenetics and Evolution, v.37, p.36-44, 2005. http://dx.doi.org/10.1016/j.ympev.2005.06.003

Henry-Silva, G. G.; Camargo, A. F. M.; Pezzato, M. M. Growth of free-floating aquatic macrophytes in different concentrations of nutrients. Hydrobiologia, v.610, p.153-160, 2008. http://dx.doi. org/10.1007/s10750-008-9430-0

Kissmann, K. G.; Groth, D. Plantas infestantes e nocivas. 2.ed. São Paulo: Basf. Tomo I, 1997. 825p.
Lacoul, P.; Freedman, B. Relationships between aquatic plants and environmenNAR factors along a steep Himalayan altitudinal gradient. Aquatic Botany, v.84, p.3-16, 2006. http://dx.doi. org/10.1016/j.aquabot.2005.06.011

Martins, D.; Costa, N. V.; Terra, M. A.; Marchi, S. R. Caracterização da comunidade de plantas aquáticas de dezoito reservatórios pertencentes a cinco bacias hidrográficas do Estado de São Paulo. Planta Daninha, v.26, p.17-32, 2008. http://dx.doi.org/10.1590/ S0100-83582008000100003

Martins, D.; Pitelli, R. A.; Tomazella, M. S.; Tanaka, R. H.; Rodrigues, A. C. P. Levantamento da infestação de plantas aquáticas em Porto Primavera antes do enchimento final do reservatório. Planta Daninha, v.27, p.879-886, 2009.

Mormul, R. P.; Ferreira, F. A.; Michelan, T. S.; Carvalho, P.; Silveira, M. J.; Thomaz, S. M. Aquatic macrophytes in the large, subtropical Itaipu Reservoir, Brazil. Revista de Biologia Tropical, v.58, p.1437-1452, 2010.

O’Hare, A. M. T.; Clarke, R. T.; Bowes, M. J.; Cailes, C.; Henville, P.; Bissett, N.; Mcgahey, C.; Neal, M. Eutrophication impacts on a river macrophyte. Aquatic Botany, v.92, p.173-178, 2010. http:// dx.doi.org/10.1016/j.aquabot.2009.11.001

Portes, T. A.; Castro Júnior, L. G. Análise de crescimento de plantas: um programa computacional auxiliar. Revista Brasileira de Fisiologia Vegetal, v.3, p.53-56, 1991.

Sarruge, J. R. Soluções nutritivas. Summa Phytopathologica, v.1, p.231-233, 1975.

Thomaz, S. M.; Bini, L. M., 1998, Ecologia e manejo de macrófitas aquáticas em reservatórios. Acta Limnologica, v.10, p.103-116, 1998.

Thomaz, S. M.; Chambers, P. A.; Pierini, S. A.; Pereira, G. Effects of phosphorus and nitrogen amendments on the growth of Egeria najas. Aquatic Botany, v.86, p.191-196, 2007. http://dx.doi. org/10.1016/j.aquabot.2006.10.004

Toledo Júnior, A. P. Informe preliminar sobre os estudos para a obtenção de um índice para avaliação do estado trófico de reservatórios de regiões quentes tropicais. São Paulo: CETESB, 1990. 12p. (Relatório Interno CETESB).

Tundisi, J. G.; Matsumura-Tundisi, T.; Abe, D. S. The ecological dynamics of Barra Bonita (Tietê River, SP, Brazil) reservoir: Implications for its biodiversity. Brazilian Journal of Biology, v.68, p.1079-1098, 2008. http://dx.doi.org/10.1590/S151969842008000500015

Xie, Y.; Wen, M.; Yu, D.; Li, Y. Growth and resource allocation of water hyacinth as affected by gradually increasing nutrient concentrations. Aquatic Botany, v.79, p.257-266, 2004. http:// dx.doi.org/10.1016/j.aquabot.2004.04.002 